\title{
阿蘇火山灰土における有機污染物質の吸着実験*
}

藤田一城 $* *$ 廣畑昌章 $* *$ 榮田智志 $* *$. 永村哲也 ${ }^{* *} \cdot$ 松下 $\quad$ 裕 $* * \cdot$ 松岡良三 $* *$

\section{Adsorption Experiments of Organic Contaminant Compounds by Aso Volcanic Ash Soil*}

\author{
Itsusei FUJITA**, Masaaki HIROHATA**, Satoshi SAKAEDA**, \\ Tetsuya NAGAMURA** ${ }^{*}$, Hiroshi MATSUSHITA** and Ryozo MATSUOKA**
}

\begin{abstract}
To investigate the adsorbability of organic contaminants on original Aso volcanic ash soil, the removal volatile organic compounds (VOC), pesticides components in the monitoring items and the environmental quality standard items in the Kankyou-kihon-hou adsorbed on the soil packed in a large column were examined in this paper. The results showed that their adsorbability was influenced by water solubility of organic contaminants and the number and kinds of hydrophilic functional groups in the compounds.
\end{abstract}

Key Words: Aso volcanic ash soil, pesticides, water-solubility, hydrophilic functional group

\section{要 旨}

阿蘇火山灰土の有機污染物質に対する吸着性を明らかにするために大型カラムを用いて 環境基本法に基づく環境基準項目および要監視項目の農薬成分および揮発性有機化合物 (污染物質) ((VOC))の負荷及びその溶出に対するいくつかの実験を行った。その結果、阿 蘇火山灰土の吸着性は有機污染物質のそれぞれの水溶解性および分子内の親水性官能基の 種類、数に影響する事が明らかになった。

キーワード：阿蘇火山扊土、農薬、揮発性有機化合物 (有機污染物質)、水溶解性、親水性 官能基

* 本論文の一部は日本地下水学会1998年秋季講演会(富山、1998年10月16日一18日)にて発表。

** 熊本県保健環境科学研究所 地下水科学室 ( 


\section{1.はじめに}

熊本平野は、従来豊かな地下水に恵まれてきた (熊本県企画開発部、1996)。しかし、地下水の揚 出量の増加と農業形態の変化等による地下水涵養 水量の減少により地下水量には変化が見られてい る(栗城、1996)。そのため熊本の地下水も僅かで はあるが減少しているといわれている(熊本県企 画開発部、1996)。そこで地下水量の増加のため に人工涵養の試みがなされている(菊池ら、1987)。 この豊かな熊本の地下水には、今も活動を続け ている阿蘇火山の火山活動噴出物の堆積が少なか らず関与しているといわれている。このような阿 蘇火山噴出物堆積物の起源の一つと考えられる現 在の阿蘇中岳火山灰土について、一般的肥料成分 の一つであるリン酸およびアンモニウムイオンの 高い吸着性が認められ、さらにイオン成分の溶出 結果は、阿蘇火山灰の関わる地域での地下水水質特 性に関与することを明らかにした(藤田ら、1998)。

地下水の涵養において地下に浸透する水は農業 用水さらに実験的人工婳養には河川等の公共域の 水が用いられる。これらの水にはリン酸およびア ンモニウムイオン以外に様々な有機污染物質の存 在が考えられる。そこで、今回阿蘇火山灰土の有 機污染物質に対する吸着性を明らかにするため、 環境基本法に基づく環境基準項目および要監視項 目の農薬成分および揮発性有機污染物質の吸着除 去能について、化学構造(化学物質の持つ官能基 の種類と数)を一つの因子として考察した。

\section{2. 実験}

\section{1 試薬}

アセトン、n一ヘキサン、ジクロロメタン、酢酸 エチルは和光純薬社製残留農薬測定用 300 使用 した。揮発性有機污染物質の測定用メタノールは、 和光純薬社製インフィニティピュアメタノールを 使用した。揮発性有機污染物質の火山灰土への負 荷及び溶出水溶液測定には、関東化学社製揮発性 有機化合物混合標準液 II を使用した。農薬の火山 灰土への負荷及び溶出水溶液測定には、関東化学 社製農薬混合標準液 1 (GC 対象13種)を使用し た。農薬測定用の固相抽出剂は、ジーエルサイエ
ンス社製 GL-pak PLS-2を用いた。揮発性有機污 染物質を測定するための水(検量線作成及び希䣋 用) は、住友精密工業社製 VOC 測定水を煮沸しケ ミカルクリーンルームで冷却して使用した。

\section{2 機器}

電気炉は、柴田科学社製セラミックマッフル CM-3000を使用した。農薬の定量には、MSD 付 きガスクロマトグラフのフィニガンマット社製マ グナムを使用した。揮発性有機污染物質の定量に は、日本電子社製磁場型質量分析装置 GC-MS DX-303S を使用した。

\section{3 火山灰土カラムへの揮発性有機污染物質及 び農薬の負荷}

阿蘇火山灰土および熱処理後の阿蘇火山灰土を 充填したカラムを既報と同様に調整した(藤田 ら、1998)。有機污染物質の負荷実験を行うため、 カラムに充填した火山灰土の最上層部の $10 \mathrm{~g}$ と揮 発性有機污染物質及び農薬の混合溶液をそれぞれに 混ぜ合わせ、そのままカラム最上層部に静置した。

\section{4 通水実験および物理化学的性状の測定}

揮発性有機污染物質及び農薬の負荷後のリン酸 アンモニウム水溶液による通水実験及び物理化学 的性状の測定は、既報 (藤田ら、1998)に従い行っ た。

\section{5 環境基本法に基づく環境基準項目および要 監視項目の農薬成分の定量}

固相抽出ガスクロマトグラフ質量分析法に従い 定量した(環境化学研究会編、1993 pp377-400)。

\section{6 環境基本法に基づく環境基準項目の揮発性 有機污染物質の定量}

ヘッドスペースガスクロマトグラフ質量分析法に 従い定量した(環境化学研究会編、1994 pp441-450)。

\section{3. 結果および考察}

\section{1 加熱による表面特性および化学成分の変化}

阿蘇火山灰土の有機污染物質に対する吸着性を 検討するため、熱処理をした阿蘇火山灰土を用い 
て検討した。阿蘇火山灰土について、電気炉を使 用して $500^{\circ} \mathrm{C}$ および $1000^{\circ} \mathrm{C} て ゙ 24$ 時間加熱し、自然 冷却により処理した火山灰土についてその表面特 性(比表面積、細孔容積、平均細孔半径)さらに蛍 光X線による酸化体の成分分析を行った。その結 果を表 1 及び 2 に示した。比表面積は、500ㄷ処 理火山灰土で非処理の 4 分の 1 に、さらに $1000^{\circ} \mathrm{C}$ による加熱で100分の 1 に減少している。細孔容 積は500ㄷ 処理火山灰土で 5 分の 1 、さらに $1000^{\circ} \mathrm{C}$ による加熱で400分の 1 にまで減少してい る。細孔半径は、 $500^{\circ} \mathrm{C}$ 処理火山灰土で非処理の 1.2 倍さらに $1000^{\circ} \mathrm{C} に よ る$ 加熱で 2 倍にまで拡大 している。

\section{2 阿蘇火山灰土への農薬の負荷}

既報（藤田ら、1998）で使用した通水実験用カラ 么装置を使用し、カラム充填火山灰土上部に環境 基準及びその要監視項目に指定されている農薬の BPMC、DDVP、プロピザミド、MEP、IBP、イソ プロチオラン、ベンチオカーブ、ダイアジノン、 CNP、CAT、TPN、イソキサチオン、EPNを10 $\mu \mathrm{g}$ 、 $50 \mu \mathrm{g} 、 500 \mu \mathrm{g}$ 負荷し、水田での一般的リン酸アン モニウムの濃度(日高、1998) と考えられる $2 \mu \mathrm{g} / \mathrm{m} \ell$ で流下するときの火山灰土への農薬の吸着性を調 べ、その結果を図 $1 、 2$ 及び 3 に示した。また、 今回使用した農薬の水への溶解性 $(\mathrm{mg} / \ell$ ) (日本植
物防疫協会編、1994) および脂溶性指標の LogPo/w （Iijima et al、1997）を表3に示した。

図 1 に示すように $10 \mu \mathrm{g}$ を負荷しても実験カラ ムの下の端より BPMC、プロピザミド、DDVPの 3 種類は、火山灰土への吸着はほとんど行われる ことなく負荷した農薬の $90 \%$ が溶出している。

BPMC と DDVPは、共に水溶解性か $500 \mathrm{mg} / \ell$ 以 上と高い。さらにDDVPは芳香環を分子内に有

表 3 環境基準項目農薬の水溶性

Table 3 Water-solubility of pesticides in the Kankyo-kihon-hou

\begin{tabular}{|c|c|c|}
\hline 農薬名 & 水溶解度 $(\mathrm{mg} / \mathrm{l}$ ) & $\mathrm{LogPo} / \mathrm{w}$ \\
\hline$\overline{\mathrm{IBP}}$ & 1000 & 3.2 \\
\hline DDVP & 1000 & 1.4 \\
\hline BPMC & 610 & 2.2 \\
\hline 价 ロチオフン & 50 & 2.6 \\
\hline ダ仍ジ は & 40 & 3.3 \\
\hline ヘンチ朸ーブ & 30 & 3.7 \\
\hline プ吡ザミ゙ & 15 & 2.5 \\
\hline MEP & 14 & 2.7 \\
\hline $\mathrm{CAT}$ & 5 & 1.6 \\
\hline イリキサチオン & 1.9 & 3.3 \\
\hline TPN & 0.6 & 2.8 \\
\hline $\mathrm{CNP}$ & 0.25 & 4.8 \\
\hline EPN & 不溶解 & 3.3 \\
\hline
\end{tabular}

表 1 阿蘇火山灰土の熱による表面物性の变化

Table 1 Change of surface properties by heat of Aso volcanic ash soil

\begin{tabular}{llll}
\hline & 比表面積 & 細孔容積 & $\begin{array}{l}\text { 平均細孔 } \\
\text { 半径 }\end{array}$ \\
& $\mathrm{m}^{2} / \mathrm{g}$ & $\mathrm{m} \mathrm{l} / \mathrm{g}$ & $\AA$ \\
\hline 未処理 & 11.898 & 0.046 & 79.34 \\
$500^{\circ} \mathrm{C}$ & 2.80 & 0.0076 & 92.4 \\
$1000^{\circ} \mathrm{C}$ & 0.17 & 0.0012 & 169 \\
\hline
\end{tabular}

表 2 阿蘇火山灰土の熱による蛍光X線の成分变化

Table 2 Change of components of fluorescence X-ray by heat of Aso volcanic ash soil

\begin{tabular}{rccccccccc}
\hline & $\mathrm{SiO}_{2}$ & $\mathrm{Al}_{2} \mathrm{O}_{3}$ & $\mathrm{Fe}_{2} \mathrm{O}_{3}$ & $\mathrm{CaO}$ & $\mathrm{Na}_{2} \mathrm{O}$ & $\mathrm{SO}_{3}$ & $\mathrm{TiO}_{2}$ & $\mathrm{~K}_{2} \mathrm{O}$ & $\mathrm{Mn}_{2} \mathrm{O}_{3}$ \\
\hline 未処理 & 55.5 & 14.55 & 13.78 & 8.03 & 3.11 & 2.01 & 1.56 & 1.39 & 0.207 \\
$500^{\circ} \mathrm{C}$ & 54.1 & & 25.49 & 11.92 & & 3.33 & 2.42 & 2.15 & 0.425 \\
$1000^{\circ} \mathrm{C}$ & 54.6 & & 27.70 & 12.56 & & & 2.20 & 2.29 & 0.382 \\
\hline
\end{tabular}




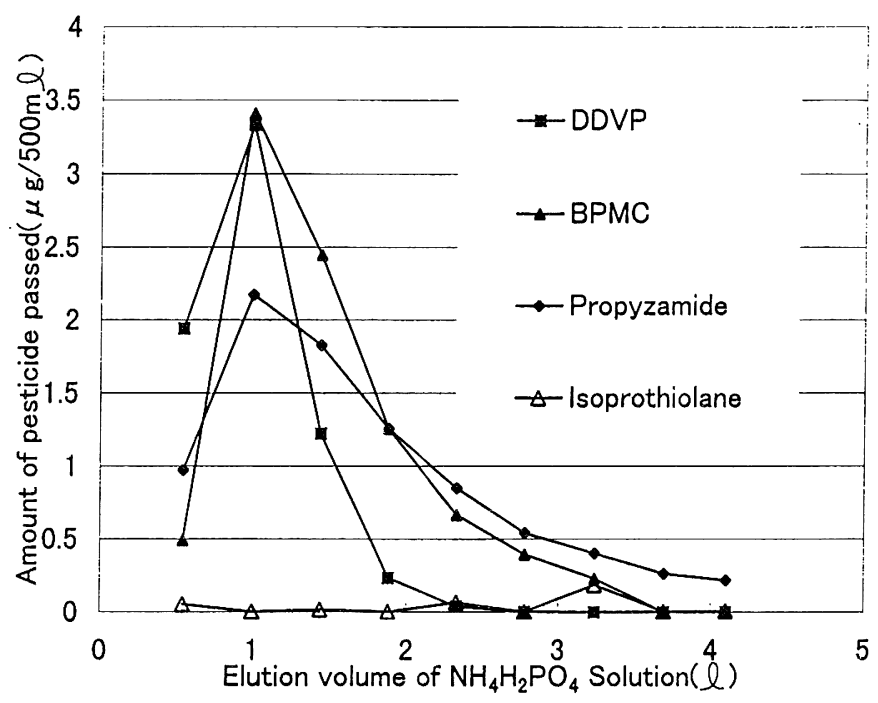

図 1 阿蘇火山灰土への農薬負荷後 $(10 \mu \mathrm{g})$ のリン酸アンモニウム溶液による溶出挙動

Fig. 1 Elution behavior of pesticides $(10 \mu \mathrm{g}$ each) from the colum packed with Aso volcanic ash soil using ammonium phosphate as an eluent (Column I.D. $89 \mathrm{~cm}$, lenth $75 \mathrm{~cm}$ flow rate $450 \mathrm{ml} / \mathrm{hr}$ )

しない直鎖のリン酸エステルであり、BPMCは分 子内に芳香環を有しているが、酸アミド結合さら にエステル結合の親水性の高い官能基を二つ有し ている。この 2 つの物質は高い水溶解性及び官能 基の土壤への疎水性相互作用による土壤吸着がほ とんど機能しないために溶出したと考えられる。 プロピザミドは、BPMC、DDVPに比較して低い 水溶解性であり、MEP とほぼ同じ水溶解性およ び $\log \mathrm{Po} / \mathrm{w}$ を示しているにもかかわらず今回実 験火山灰土カラムへは吸着されず溶出している。 これは、プロピザミドが BPMC と同じ酸アミド の親水性官能基を持つために土壤への疎水性相互 作用による土壤吸着がほとんど機能しないために 溶出していると考えられる。その他の農薬につい ては、10 $\mu \mathrm{g}$ の負荷では溶出は見られない。

$50 \mu \mathrm{g}$ と $500 \mu \mathrm{g}$ の農薬を負荷したときの結果を 図 2、3に示した。MEP、イソプロチオラン、ベ ンチオカーブは LogPo/w の低い順番に、負荷し た農薬量の $40 \%$ が溶出している。また水溶解性が $500 \mathrm{mg} / \ell$ 以上の IBP は (BPMC、プロピザミド、 DDVPのように負荷した農薬の $90 \%$ 量の溶出では ないが) $60 \%$ 近くの溶出がみられる。

$500 \mu \mathrm{g}$ 負荷後の溶出において CNP が僅かに溶 出が見られるが、その他のダイアジノン、CAT、 TPN、イソキサチオン、EPN は全く負荷後の溶
出が見られない。ダイアジノン以外は水への溶解 度(表 3 ) は $5 \mathrm{mg} / \ell$ 以下で非常に水溶解性が低い ために土畩への吸着反応が起きていると考えられ る。ただしダイアジノンは、CNP、TPN、イソ キ开チン、EPNに比較して水溶解度は高い值 を有しているが、分子内のピリミジン骨格による 分子内のイオン性による吸着が大きく働いている可 能性が高いために溶出が見られないと考えられる。

\section{3 阿蘇火山灰土への揮発性有機化合物の負荷}

農薬成分は水溶解性が低く、火山灰土に対して 負荷後に溶出が見られないものがある。そこで農 薬より低分子であり水溶解性も高い揮発性有機化 合物に対する吸着性を検討した。11項目の揮発性 有機污染物質を $100 \mu \mathrm{g}$ 負荷し $2 \mu \mathrm{g} / \mathrm{m} \ell$ のリン酸ア ンモニウム水溶液で流下するときの火山灰土への 吸着性を調べ結果を図 4 に示した。なお、11項目 の揮発性有機污染物質の略号と水溶解性 $(\mathrm{g} / \ell)$ (環境庁 1994)を表 4 に示した。水溶解度が 2.0g/lをこえるジクロロメタン、シス 1,2-ジクロ ロエチレン、シス1,3-ジクロロプロペン、トラン ス1,3-ジクロロプロペン、1, 1, 2-トリクロロエ夕 ンを阿蘇火山灰土に負荷しても吸着されることな く溶出をしている。ただしシス1,2-ジクロロエチ レンは僅かではあるが吸着される。また、水溶解 

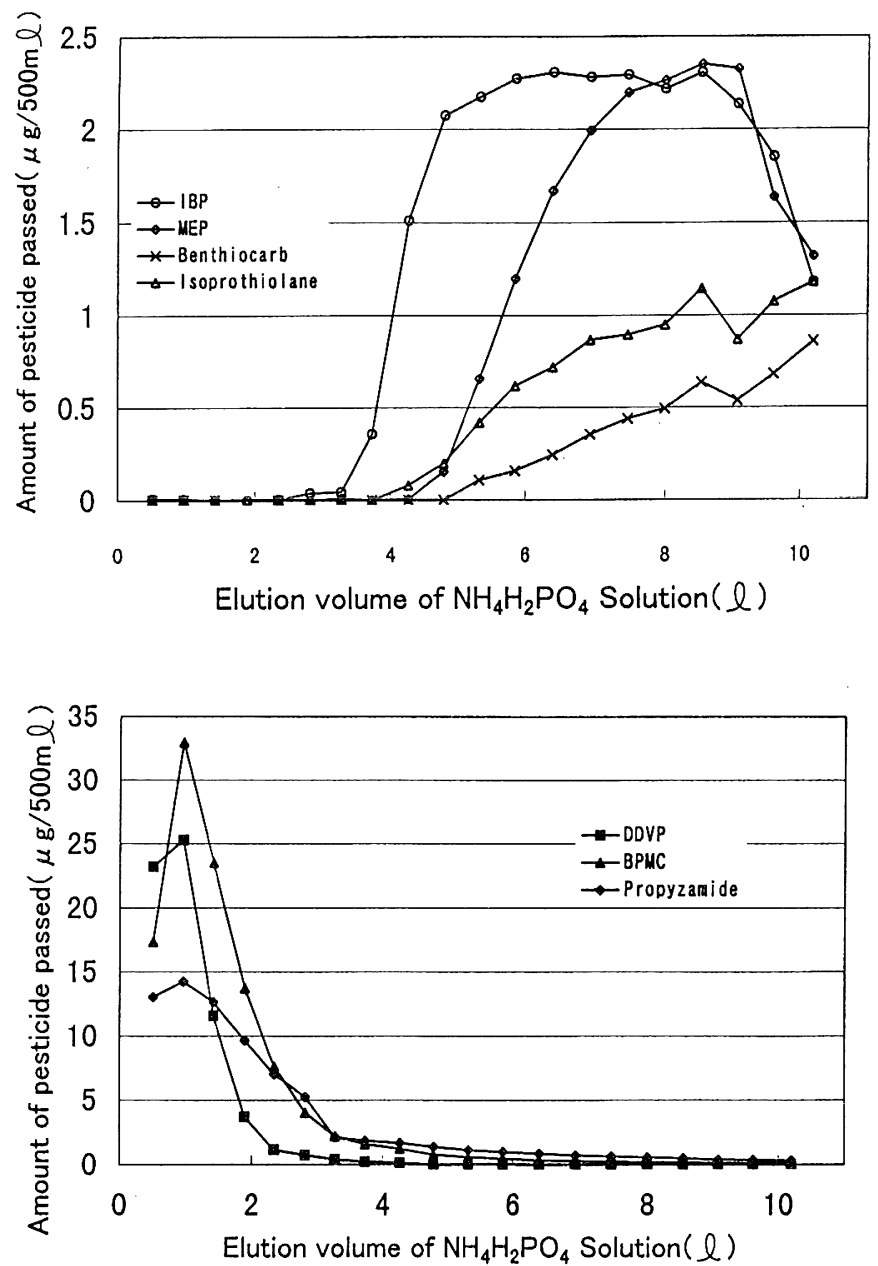

図 2 阿蘇火山灰土への農薬負荷後 $(50 \mu \mathrm{g})$ のリン酸アンモニウム溶液による溶出挙動

Fig. 2 Elution behavior of pesticides $(50 \mu \mathrm{g}$ each) from the colum packed with Aso volcanic ash soil using ammonium phosphate as an eluent (Column I.D. $89 \mathrm{~cm}$, lenth $75 \mathrm{~cm}$ flow rate $450 \mathrm{ml} / \mathrm{hr}$ )

性が $2.0 \mathrm{~g} / \ell$ 以下のトリクロロエチレン、テトラク ロロエチレン、1, 1, 1-トリクロロエタン、四塩化 炭素は、一部が火山灰土に吸着され一部がカラム より溶出している。

\section{4 加熱処理火山灰土への有機污染物質の吸着}

\section{4 .1 農薬の吸着}

農薬の土壌への吸着性は、一般的には土塞に含 まれる有機性物質との相互作用である(中野、 1991) と言われている。阿蘇火山灰土中に含まれ ると考えられる有機物の影響を検討するため及び 吸着のための表面特性を変化させ未処理火山灰土 の有機污染物質 (今回の実験で使用)に対する吸着

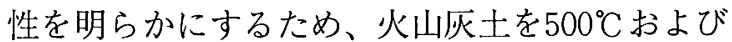
$1000^{\circ} \mathrm{C}$ で処理して実験カラムに充填し、農薬 $10 \mu \mathrm{g}$ を負荷し $2 \mu \mathrm{g} / \mathrm{m} \ell$ のリン酸アンモニウム水溶液で 流下するときの火山灰土への吸着性を図 5、6に 示した。

$500^{\circ} \mathrm{C}$ おび $1000^{\circ} \mathrm{C}$ で熱処理した火山灰土は比 表面積が非加熱の火山灰土に比較し $1 / 4$ から $1 / 100$ に変化するときの農薬の吸着性は、図 6 に示すよ うに大きく変化している。図 1 および図 5 では、 全くカラムより溶出の見られないダイアジノン、 CNP、CAT、TPN、イソキサチオン、EPN(火山 灰土に完全に捕集されている)についても、 $1000^{\circ} \mathrm{C}$ で処理した阿蘇火山灰土と相互作用を起こ 

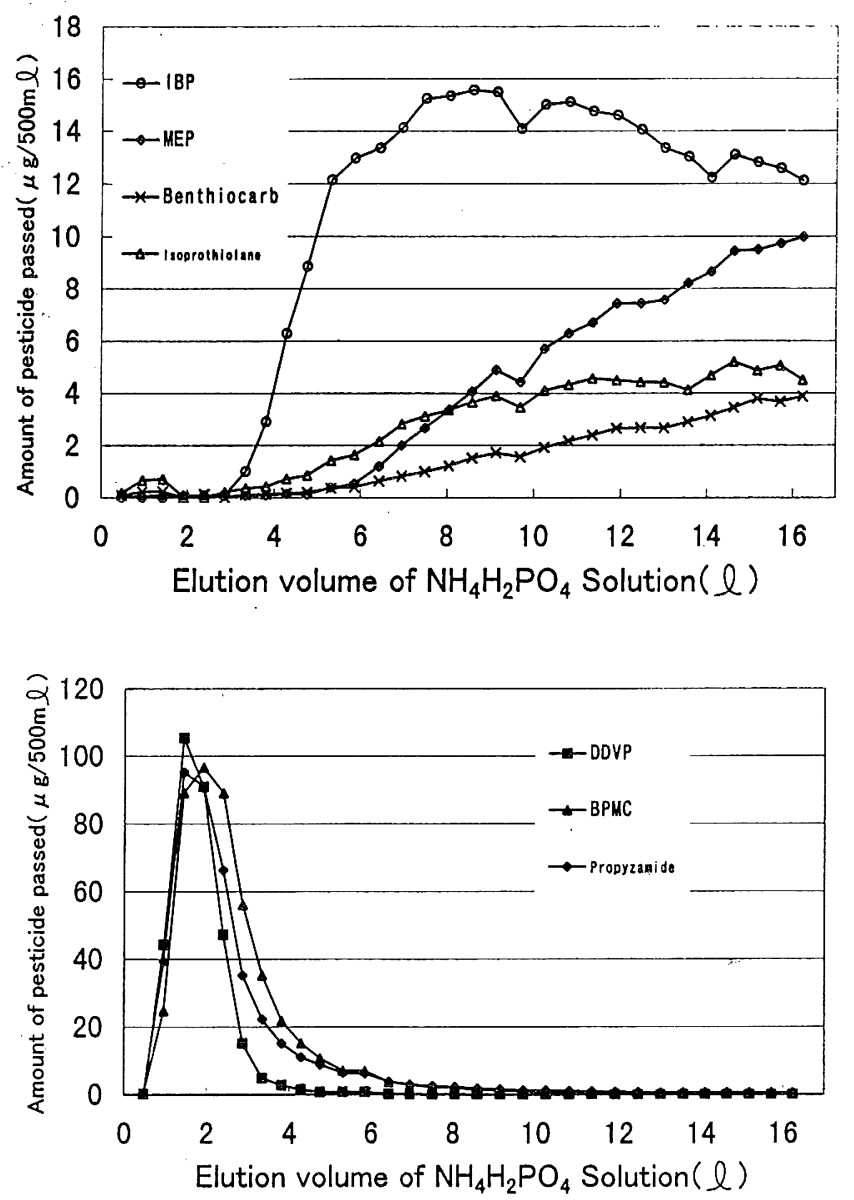

图 3 阿蘇火山灰土への農薬負荷後 $(500 \mu \mathrm{g})$ のリン酸アンモニウム溶液による溶出挙動

Fig. 3 Elution behavior of pesticides $(500 \mu \mathrm{g}$ each) from the colum packed with Aso volcanic ash soil using ammonium phosphate as an eluent (Column I.D. $89 \mathrm{~cm}$, lenth $75 \mathrm{~cm}$ flow rate $450 \mathrm{ml} / \mathrm{hr}$ )

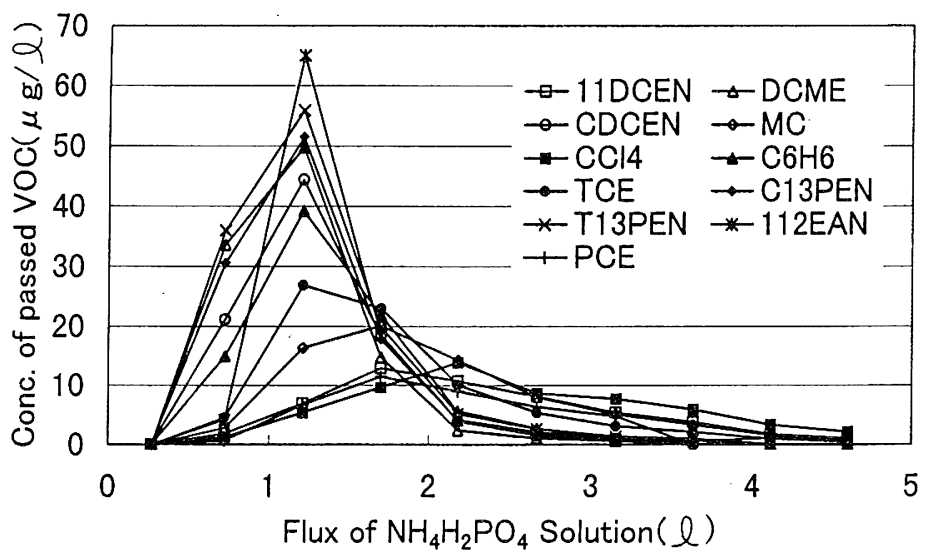

図 4 阿蘇火山灰土への VOC 負荷後 $(10 \mu \mathrm{g})$ のリン酸アンモニウム溶液による溶出挙動

Fig. 4 Elution behavior of VOC ( $10 \mu \mathrm{g}$ each) from the colum packed with Aso volcanic ash soil using ammonium phosphate as an eluent (Column I.D. $89 \mathrm{~cm}$, lenth $75 \mathrm{~cm}$ flow rate $450 \mathrm{ml} / \mathrm{hr}$ ) 
表 4 揮発性有機化合物の水溶性

Table 4 Water-solubility of Volatile organic compounds in the Kankyo-kihon-hou

\begin{tabular}{|c|c|c|}
\hline 揮発性有機化合物名 & 略号 & 水溶解度 $(\mathrm{g} / \mathrm{l})$ \\
\hline 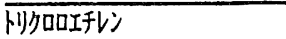 & TCE, & 1.07 \\
\hline テトラクロ姓チン & PCE & 0.15 \\
\hline 1,1,1,一訬年吅多 & $\mathrm{MC}$ & 0.044 \\
\hline 四塩化炭素 & $\mathrm{CCl} 4$ & 0.8 \\
\hline ジクロ将 & DCME & 20 \\
\hline 1,1,2,一トリ吅工多 & 112EAN & 4.5 \\
\hline $1,1,-シ ゙$ ク吅エレン & 11DCEN & 2.25 \\
\hline 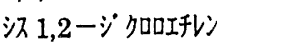 & CDCEN & 3.5 \\
\hline 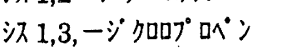 & C13PEN & 2.7 \\
\hline 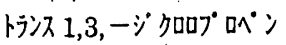 & T13PEN & 2.8 \\
\hline ペ准ン & $\mathrm{C} 6 \mathrm{H} 6$ & 1.8 \\
\hline
\end{tabular}

すことなく溶出している。

ただし、ダイアジノンは、分子内にピリミジン 骨格を有するために他の農薬に比較して表面積を 殆ど有していない状態(含有有機物も皆無と考え られる) の $1000^{\circ} \mathrm{C}$ 処理火山灰土とも相互作用を有 している。ダイアジノンは CNP、CAT、TPN、 イソキサチオン、EPNに比べ高い水溶解性を有 しているにもかかわらず非熱処理の火山灰土に対 し負荷後の溶出がCNP、CAT、TPN、イソキサ チオン、EPNと同様全く見られないことを裏付 けるものである(図 1)。ダイアジノンは、土壤そ のものへの高い吸着性があることを示していると 考えられる。
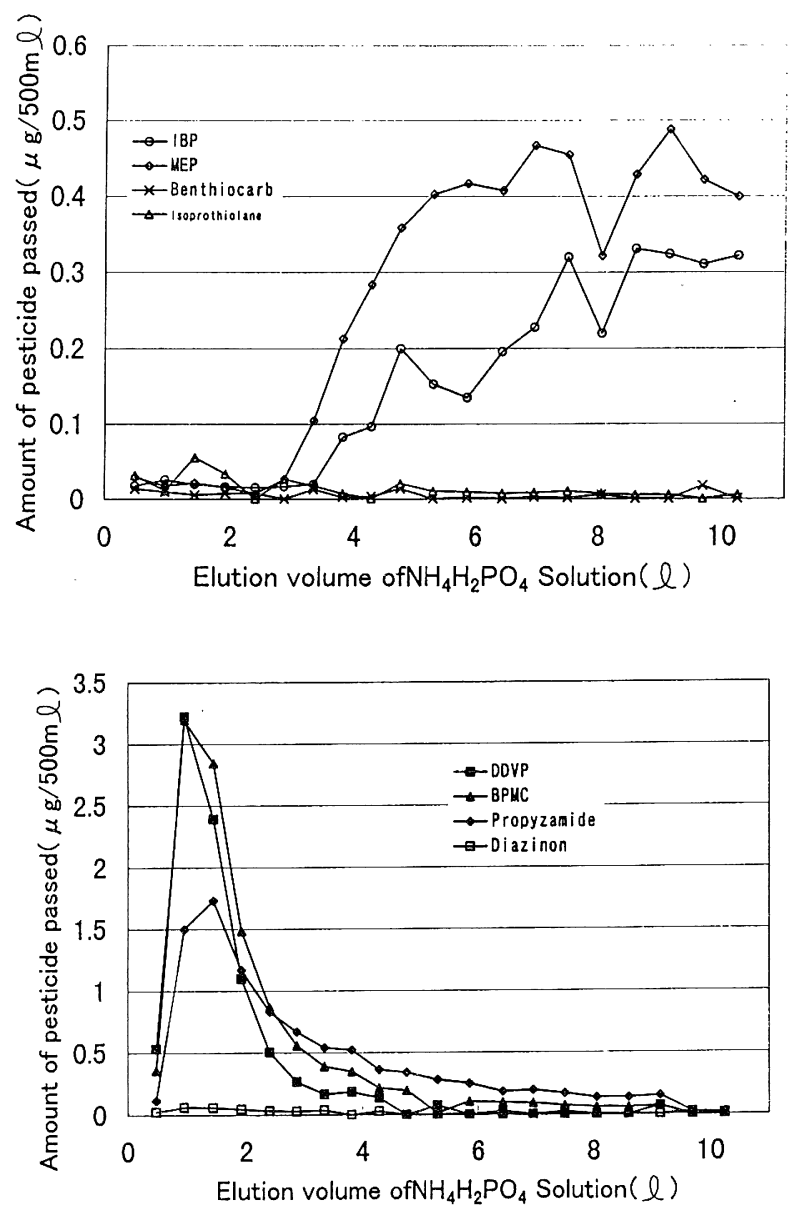

図 $5500^{\circ} \mathrm{C}$ 熱処理阿蘇火山灰土への農薬負荷後 $(10 \mu \mathrm{g})$ のリン酸アンモニウム溶液による溶出挙動

Fig. 5 Elution behavior of pesticides $(10 \mu \mathrm{g}$ each) from the colum packed with Aso volcanic ash soil treated at $500^{\circ} \mathrm{C}$ using ammonium phosphate as an eluent (Column I.D. $89 \mathrm{~cm}$, lenth $75 \mathrm{~cm}$ flow rate $450 \mathrm{ml} / \mathrm{hr}$ ) 

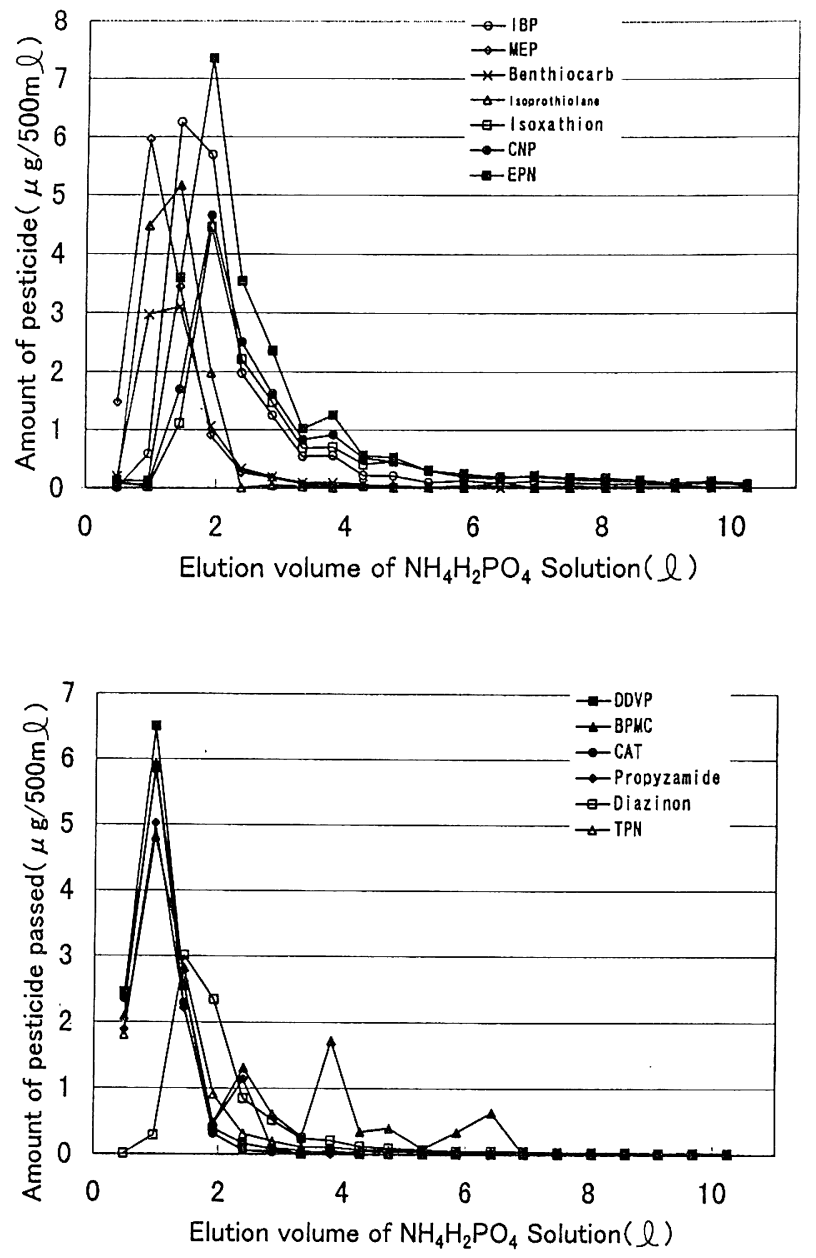

图 $61000^{\circ} \mathrm{C}$ 熱処理阿蘇火山灰土への農薬負荷後 $(10 \mu \mathrm{g})$ のリン酸アンモニウム溶液による溶出挙動

Fig. 5 Elution behavior of pesticides $(10 \mu \mathrm{g}$ each) from the colum packed with Aso volcanic ash soil treated at $1000^{\circ} \mathrm{C}$ using ammonium phosphate as an eluent (Column I.D. $89 \mathrm{~cm}$, lenth $75 \mathrm{~cm}$ flow rate $450 \mathrm{ml} / \mathrm{hr}$ )

\subsection{2 揮発性有機化合物の吸着}

農薬の阿蘇火山灰土への吸着性は、未処理火山 灰土と $500^{\circ} \mathrm{C}$ 熱処理火山灰土との間に大きい違い は見られない。さらに末処理火山灰土への揮発性 有機污染物質の吸着性が殆ど見られていない。そ こで $1000^{\circ} \mathrm{C}$ で処理した阿蘇火山灰土に揮発性有機 污染物質 $100 \mu \mathrm{g}$ を負荷し $2 \mu \mathrm{g} / \mathrm{m} \ell$ のリン酸アンモ 二ウム水溶液で流下するとき揮発性有機污染物質 の負荷後溶出挙動を検討した。

揮発性有機污染物質の土壤負荷後の溶出濃度に おいて $1000^{\circ} \mathrm{C} て ゙$ 処理した阿蘇火山灰土と未処理のあ いだには大きい変化は見られない(結果は示さず)。

\section{4. まとめ}

熊本の地下水には今も活動を続けている阿蘇火 山の火山活動噴出物の堆積が少なからず関与して いるといわれている。このような阿蘇火山噴出物 堆積物の起源の一つと考えられる現在の阿蘇中岳 火山灰土について、人工涵養実験の一つとして有 機污染物質に対する吸着性を明らかにするために 大型カラムを用いて環境基本法に基づく環境基準 項目および要監視項目の農薬成分および揮発性有 機污染物質の負荷及びその溶出に対するいくつか の実験を行った。その結果、阿蘇火山灰土の吸着 
性は有機污染物質のそれぞれの水溶解性および分 子内の親水性官能基の種類、数に影響する事が明 らかになった。

\section{参考文献}

栗城 稔 (1996)：人工涵養の技術、地下水学会誌 39 、 $33-45$.

熊本県企画開発部 (1996)：『熊本の水資源』、p11-33. 菊池良介・井原邦明・依光春実(1987)：阿蘇西麓台地 における散水実験について、地下水学会誌、29、 9-18.

藤田一城・廣畑昌章 ・松崎達哉・松下 裕 ・松岡良三 （1998）：阿蘇火山灰土によるリン酸及びアンモニウ ムイオンの吸着と地下水のイオン組成への影響、衛 生化学、44、386-391.

環境化学研究会編 (1993)：『環境水質分析法マニュア
ル』P377-400.

環境化学研究会編 (1994）:『新しい排水基準とその分析 法』P441-450.

日高 伸 (1998)：土と水と食品の硝酸をめぐる諸問題 シンポジュウム講演資料 pp68-75、東京.

日本植物防疫協会編(1994)：『農薬ハンドブック』日 本植物防疫協会.

Iijima K., Saka M., Odanaka Y. and Matano O. (1997) "Multiresidue Analytical Method of Pesticides by GC-MS" J. Pesticide Science 22, 17-26.

環境庁編 (1994)：『化学物質環境データー集』.

中野政詩 (1991)：「土の物質移動学」東京大学出版会、 p131-146.

日本化学会編 (1993)：「土の化学」学会出版センター P168-173.

(受付：1998年12月 4 日、受理：1999年 3 月30日) 